\title{
Melanokortin Sistemi: İştah ve Enerji Homeostazı Etki Mekanizmaları
}

\author{
Ela Altun ${ }^{\text {a1,*}, ~ S a b i h a ~ Z e y n e p ~ A y d e n k ~ K o ̈ s e o g ̆ l u ~}{ }^{\mathrm{a} 2}$ \\ a İstanbul Sabahattin Zaim Üniversitesi, Lisansüstü Ĕ̆itim Enstitüsü, Beslenme ve Diyetetik Bölümü, İstanbul, Türkiye \\ b İstanbul Sabahattin Zaim Üniversitesi, Sağlık Bilimleri Fakültesi, Beslenme ve Diyetetik Bölümü, İstanbul, Türkiye \\ İstanbul Sabahattin Zaim Üniversitesi Fen Bilimleri Enstitüsü Dergisi (2021) 3 (3): 212-219 \\ https://doi.org/10.47769/izufbed.1027766 \\ (iD) $O R C I D{ }^{1} 0000-0003-4129-6955 ;{ }^{2} 0000-0001-7936-8462$
}

\begin{tabular}{l}
\hline YAYIN BİLGİSİ \\
\hline Yayın geçmişi: \\
Gönderilen tarih: 24 Kasım 2021 \\
Kabul tarihi:30 Aralık 2021 \\
\hline Anahtar kelimeler: \\
Melanokortin \\
Iştah \\
Enerji dengesi \\
Hormon \\
Beslenme \\
Çocukluk çağı obezitesi
\end{tabular}

\begin{abstract}
ÖZET
İştah ve enerji dengesi uzun yıllardır araştırmalarla aydınlatılmaya çalışılmaktadır. Beyindeki melanokortin sistemi bu dengenin korunmasında önemli bir role sahiptir. İşlevlerini vücuttaki farklı mekanizmalarla sağlar. Bu mekanizmalar; hormonlar, dopamin, AMPK, egzersiz, diyet, immünoglobülinler ve lipokalin-2 ile ilişkilidir. Melanokortin sisteminin işleyişindeki bozukluklar başta çocukluk çağı obezitesi olmak üzere birçok metabolik sendroma sebep olur. Diyete bağlı veya genetik varyasyonların sebep olduğu bu durumların tedavi yollarını geliştirmek birçok hastalık için önemli olabilir. Bu derlemede, melanokortin sisteminin iştah ve enerji dengesindeki çalışma prensipleri ve besinlerle olan ilişkileri incelenmiştir.
\end{abstract}

\section{Melanocortine System: Appetite and Energy Homeostasis Mechanisms}

\begin{tabular}{l}
\hline ARTICLE INFO \\
\hline Article history: \\
Received: 24 November 2021 \\
Accepted: 30 December 2021 \\
\hline Keywords: \\
Melanocortin \\
Appetite \\
Energy Balance \\
Hormone \\
Nutrition \\
Chilhood Obesity
\end{tabular}

\begin{abstract}
The appetite and energy balance has been tried to be exposed with researches for many years. Melanocortin system has an important role in maintaining this balance in the brain. It provides its functions with different mechanisms. The mechanisms; it is associated with hormones, dopamine, AMPK, exercise, diet, immunoglobulins and lipocalin-2. Malfunctions in the functioning of the melanocortin system cause many metabolic syndromes, especially childhood obesity. It may be important for many diseases to develop treatment methods for these conditions caused by diet-related or genetic variations. In this review, the working principles of the melanocortin system in appetite and energy balance and its relations with foods are examined.
\end{abstract}

\section{Giriş}

Besin alımını ve enerji homeostazını düzenleyen vücudumuzda birçok sistem vardır (Lieu vd. 2020). Bu sistemlerden biri olan, beynin hipotalamus bölgesi, beslenme davranışının düzenlenmesinde oldukça önemli bir rol oynamaktadır (Vehapoğlu vd. 2016; Lieu vd. 2020). Yıllar boyu çeşitli çalışmalarla hipotalamustaki nöron gruplarının görevleri araştırılmış ve iştahla olan ilişkisi incelenmiştir. Hipotalamusta iştah metabolizmasını ve enerji homeostazını düzenleyen bu önemli yapı hipotalamusun arkuat çekirdeğindeki (ARC) melanokortin sistemidir. $\mathrm{Bu}$ fonksiyonlardaki yetersizlik obezite başta olmak üzere birçok metabolik hastalıklara sebep olmaktadır. Çocukluk çağı 
obezite başta olmak üzere, iştah metabolizmasında birçok alt rolleri bulunmaktadır (Micioni Di Bonaventura vd.2020). Melanokortin sisteminde, sinir hücrelerinden beynin diğer bölümlerine sinyaller gönderen iki ayrı nöronal grup bulunur (Butler vd. 2017; Toda vd. 2017). Bu bölgeler, proopiomelanokortin (POMC) nöronlarından ve agouti ile ilişkili protein (AgRP) ekspresyonu yapan nöronlardan oluşur (Toda vd. 2017, Wang vd. 2021). Arkuat çekirdek nöronlarından, iştah dengesini düzenleyen bazı peptitler salınır. POMC nöronlarından iştah baskılayıcı peptitler, agouti ile ilişkili nöronlardan ise oroksijenik etkili peptitler salgılanır. POMC nöronları enerji tüketimini arttırken, AgRP nöronları enerji tüketimini azaltmaktadır (Lieu vd. 2020). Bu nöronların sinyalleşmesinde görevli yer alan beş reseptör tipi bulunmaktadır. Melanokortin-1 reseptörü (MC1R) deride üretilirken, cilt renginin değişiminde de etkilidir. Yeni bir çalışmaya göre, makrofajlar tarafından da eksprese edilen ve ateroskloroza karşı antiinfilamatuar görevi de olan MC1R'nin alfa melanosit ligandıyla birlikte kolestrol taşınmasında yardımcı bir görev sağladığı bulunmuştur (Rinne vd. 2017). Melanokortin-2 (MC2R) reseptörü adrenal kortekste üretilerek, streoid yapılı hormon sentezinde görevlidir. Melanokortin-5 reseptörü (MC5R) mekanizması net olarak açıklanmasa da ekzokrin hücrelerde görevli olduğu bilinmektedir. (Ericson vd. 2017) Bu sistemde iştahla doğrudan görevli reseptörler ise melanokortin-3 (MC3R) ve melanokortin-4 (MC4R) reseptörleridir. Çeşitli sinyaller yoluyla besin alımını ve enerji dengesini etkilemektedir. Melanokortin sistemi sadece iştah ve enerji metabolizmasında değil, farklı fonksiyonlarda da etkilidir. Boy uzaması, kemik ve mineral yoğunluğu, insülin salgısı, pigmentasyon, steroid yapımı, hormon sentezi, ekzokrin sekresyon, vücut sıcaklığı, immün yanıtını düzenleme, analjezi, kardiyovasküler düzenleme ve nöromüsküler rejenarasyon dahil olarak nöronal yol aracılığıyla çeşitli fizyolojik görevleri vardır (Yıldırım, 2020; 54 Huang vd. 2017). Son y1llarda melanokortin sistemindeki bu nöral grupların karmaşık yapısı hakkında klinik ve farmakolojik çalışmalar arttırılarak başta obezite olmak üzere çeşitli hastalıklarla ilişkisi üzerinde durulmuştur (Toda vd. 2017). Bu derlemede, melanokortin sisteminin iştah ve enerji homeostazı üzerindeki kontrolünü ve diyetle olan ilişkisini incelemek amaçlanmıştır.

\section{Melanokortin Peptitleri ve Mekanizması}

Öncü bir polipeptit olan POMC, hipofiz başta olmak üzere, hipotalamusun kavisli çekirdeğinde ve beyin sapındaki soliter sistemin çekirdeğinde yapılır. Bunun dışında, gastrointestinal sistem, adrenal, dalak, akciğer ve tiroid dahil olarak birçok çevresel dokularda ve bağışıklık sisteminde bulunur (Kim vd. 2014). Melanokortin peptitleri, POMC geninin transkripti sonucu ortaya çıkan translasyon ürünleri olup bunlar; melanosit uyarıc hormonlar olan, $\alpha-\mathrm{MSH}, \beta-\mathrm{MSH}, \gamma-\mathrm{MSH}$ ve adrenokortikotropik hormon (ACTH)'dur (Garfield vd. 2015; Yıldırım, 2020). Bunların yanı sıra KLIPS, $\beta$-endorfin ve $\beta$ lipotropin gibi diğer peptitler de meydana gelir (Ericson vd. 2017). Melanokortin peptitleri, POMC'dan salgilandiktan sonra agonist ligandlar olan melanokortin reseptörleriyle etkileşime girerek vücutta birçok fizyolojik görevde etkili olurlar (Butler vd. 2017). Bu reseptörler melanokortin 1'den 5'e kadar numaralandırılmıştır.

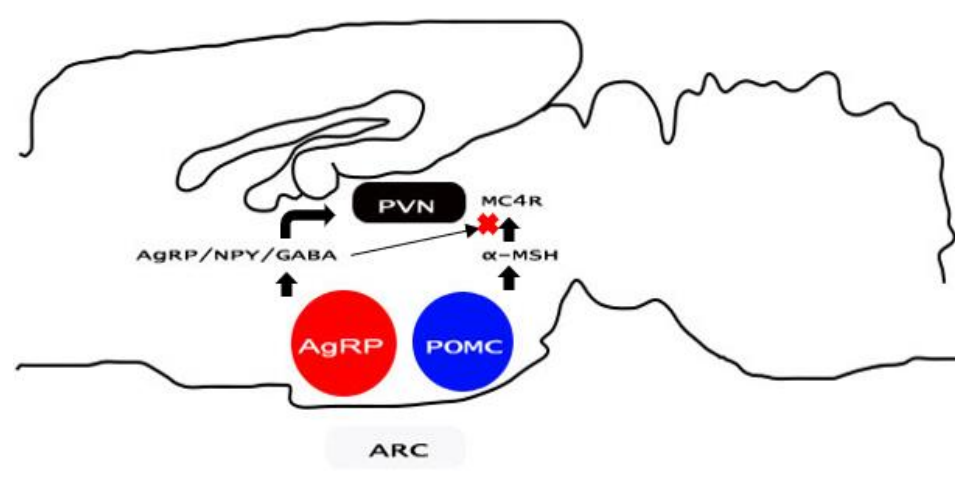

Şekil 1. Melanokortin Sistem Nöronları

MC3R ve MC4R, beyinde yüksek oranda üretilerek, diğer reseptörlere göre iştah ve metabolik kontrollerde daha etkin rol üstlenmişlerdir. Yapılan çalışmalara göre melanokortin reseptörü yardımc1 protein 2'nin (MRAP2) de gen yapılanmasının yokluğu obeziteyle ilişskili bulunmaktadır. $\mathrm{Bu}$ reseptör, enerji ve glikoz homeostazında önemli göreve sahiptir (Anderson vd. 2016)

MC4R uzun süreli iştah sinyali için önemlidir (Huang vd. 2017; Yıldırım, 2020). MC4R ayrica hepatik glukoz üretiminde ve insülin duyarlılığının düzenlenmesinde de önemli rollere sahiptir (Xu vd. 2011) Melanokortin peptidlerinin kendine özgü reseptör afinitesi bulunmaktadır. Bunlardan; $\gamma-\mathrm{MSH}, \mathrm{MC} 3 \mathrm{R}$ 'ler için, alfa MSH ise MC4R ve MC3R için daha çok afiniteye sahiptir (Butler vd. 2017). POMC nöronları; leptin, kolesistokinin, sekretin, insülin, açilghrelin, trioid hormonu, glukagon benzeri peptit-1, glukokortikoidler, interlökinler, serotonin, tiroid, glutamat, öreksin, glukoz, östrojen gibi salınımlarla ve midenin gerginliği gibi periferik metabolik sinyallerin iletilmesi ile uyarılır (Suyama vd. 2017) ve bu durum melankortin peptitlerini aktive eder. Bu hormonların hipotalamusdaki oluşturduğu sinyaldeki kesintiler bazı sorunlar ortaya çıkartabilir. Arkuat melanokortin sisteminde, AgRP nöronlarında insülinin geçici olarak yokluğunun sonucu olarak, farelerde hepatik glukoz üretiminde kusurlara sebep olduğu ve insülin direnci geliştiği bildirilmiş olup, bu da melanokortin sisteminin glikoz homeostazı üzerinde önemli bir etkisi olabileceğini göstermektedir (Kim vd. 2014). Melanokortin peptitleri paraventriküler çekirdekteki (PVH) reseptörlerle etkileşimiyle, $G$ proteni kompleksinin $(\alpha, \beta$, uyarıcı alt biriminine bağlanarak adenilat siklaz (AC) aktivitesini arttırır ve siklik adenozin monofosfat (cAMP)'nin yükselmesine neden olur. Adenozin monofosfat, glikojenin ve lipitlerin yıkımını kontrol ederek bu yolla da enerji homeostazını sağlar. Tüm bunların sonucunda melanokortin reseptör tokluk sinyalini ileterek gıda alımı inhibe eder (Butler vd. 2017; Glas vd. 2016).

POMC yolağı sadece nörol yolla değil, termal düzenlemeyle de enerji harcamasını sağlar. Vücut sıcaklığını arttırarak iskelet kasında serbest yağ asidi oksidasyonunu arttırdığ hipermetabolik aktivite gösterdiği bildirilmiştir. Melanokortinin yağların parçalaması ve enerji tüketiminde aktif rol oynadığı kanıtlanmıştır (Mounjoy, 2015; Vehapoğlu vd. 2016). Çalışmalarda melanokortin sisteminin aktivitesinin azalması, melanokortin-efferent vagal sinir yolu aracılığıyla, 
artmış yağ dokusuna ve obeziteye neden olduğu gösterilmektedir (Holland vd. 2019).

PVH'deki MC4R daha çok iştahı düzenlemek için gerekliyken, kolinerjik preganglionik parasempatik nöronlarda ifade edilen MC4R'ler enerji tüketimini arttırmak için gereklidir (Anderson vd. 2016). ARC POMC nöronlarının yokluğu ya da genlerde, reseptörlerde ve ligandlarda meydana gelen zarar verici mutasyonlar sonucu bu yolak bozulabilir. Bunun sonucunda canlı hiperfajik bir tablo seyrederek, enerji harcamasını azaltabilir. İlaveten, kardiyovasküler hastalıklara da sebep olabilir (Khodarahmi vd. 2020; van der Klaauw vd. 2016).

ARC'da bulunan bir diğer iştahı etkileyen AgRP geni tarafından eksprese edilen AgRP peptiti en güçlü ve uzun süreli iştah uyarıcıları arasındadır. AgRP ekspresyonu; beyin, adrenal bezler, akciğer ve böbrek dahil olmak üzere birçok dokuda rapor edilmiştir (Vehapoğlu vd. 2017). AgRP nöronların uyarımı oreksijenik hormon ve ghrelinin yanı sıra lezzetli besinlerin görseli ve kokusu ile de gerçekleşir (Anderson vd. 2016). Bunun dışında AgRP nöronlarını bloke edici olarak serotonin veya leptin gibi anoreksijenik hormonlar da bulunmaktadır (Kim vd. 2014; López, 2018).

Açlık sinyali üzerine, AgRP nöronlarından; aguti ile ilişkili protein, nöropeptid Y(NPY) ve birlikte eksprese edilen GABA salınır. Bunun sonucunda hızlı bir şekilde beslenme artışı ve enerji tüketiminde azalma meydana gelir. Bununla birlikte hücre içindeki cAMP seviyelerini direkt düşürdüğü ve katabolik aktiviteleri sınırlandırdığı da bilinmektedir (Ericson vd. 2017; Glas vd. 2016). Bu nöronlardaki mutasyon ya da ablasyon anoreksiye neden olur ve gida alımını arttırıcı denge bozulur (Butler vd. 2017).

\section{Melanokortin Peptit Agonistleri ve Antagonistleri}

Melanokortin peptitlerin ve reseptörlerin aktivitesi ayrıca endojen antagonistler olan aguti ile ilişkili protein nöropeptit Y tarafindan düzenlenir. Bunlar hem antagonist hem de ters agonist etki gösterebilirler. Aguiti ile ilişkili protein ve nöropeptid Y hem kendi yolağını kullanarak iştah arttırıcı etki gösterir, hem de rekabetçi bir şekilde POMC yolağına girerek MC4R ve MC3R aktivitesini bloke edip kişinin doygun olma halinden aç haline geçişini sağlar (Kim vd. 2014). Zaman içerisinde melanokortin sistemine etki eden sentetik agonist ve antagonist farmokolojik ajanlar keşfedilmiştir. Bu agonist ligandlar (RM-493, Melanotan 2, LY-2112688, Setmelanoid, $\mathrm{Ca}+2$, BIM-22493...) melanokortin reseptörlerinin ve melanosit uyarıcı hormonun etkisini arttırarak POMC geni eksikliği ya da mutasyonu olanlarda; periferik insülin duyarlılığını arttırma, kemirgenlerde ve insan dışı primatlarda glikoz toleransını arttırma, kan lipid seviyesini düşürme gibi melanokortin sisteminin yararlı etkilerini sentetik olarak sağlamaktadırlar (Yu vd.2020; Haws vd. 2020). Ancak bunların, kan basıncı ve kalp hızının artması gibi yan etkileri bulunmaktadir (Ericson vd. 2017).

Yapılan çalışmalarda MC4R reseptör eksikliği olan obez farelerde düşük kan basıncı gözlenirken, aktif MC4R reseptöre sahip farelerde yüksek kan basıncı gözlenmiştir. Bu durum melanokortin sisteminin santral sinir sistemi aracılığıyla tansiyon üzerine etkisini olabileceğini gösteren bir kanıt oluşturmaktadır (Hammad vd. 2020). Bunların dışında
POMC ligandlarına ve reseptörlerine ters etki gösteren, aguiti ile ilişkili proteinin agonisti olan antagonistlerde vardır. Bunlar beyne enjekte edildikten sonra hizla gida alımına ve kilo artışına sebep olurlar. En bilinenleri SHU antagonistidir (Ericson vd. 2017).

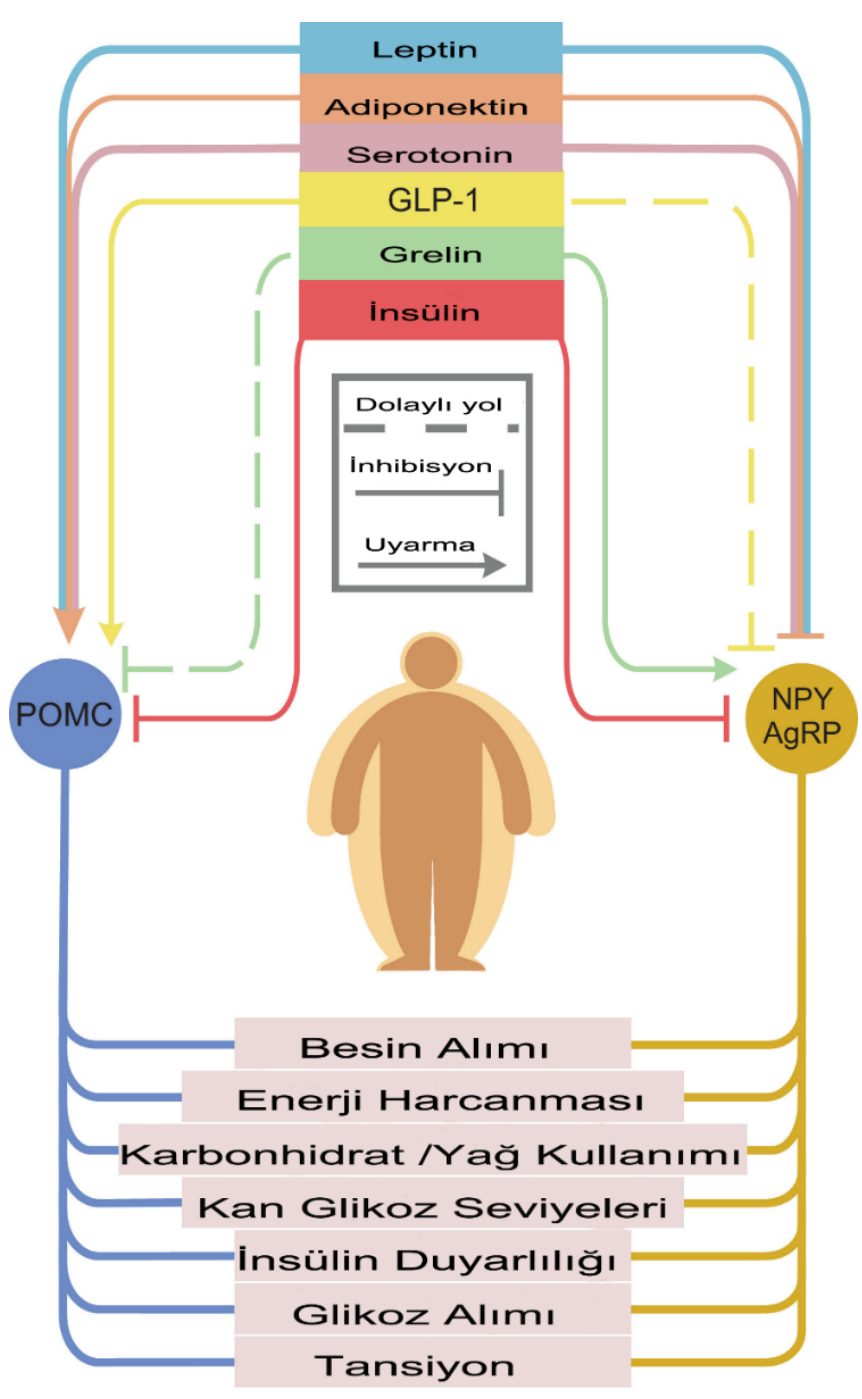

Şekil 2. POMC ve NPY/AgRP nöronlarının metabolik sinyale bağlı regülasyonu ve metabolizma üzerine etkileri (Lieu vd. 2020)

\section{Melanokortin Sistemin Etkilediği Faktörler}

\section{1. Çocukluk Çağı Obezitesi}

Bebeklikten beri gelişen ya da ergenlikte ortaya çıkan bazı obezite türlerinin bu mutasyonların etken olduğu çalışmalarla açığa çıkarılmıştır (Trier vd. 2020; Butler vd. 2017). Obez çocukların $\alpha$-MSH plazma seviyeleri, normal ve düşük kilolu akranlarına göre önemli ölçüde daha düşük gösterilmektedir. $\mathrm{Bu}$ durum, a-MSH'nin çocukluk obezitesinde ve iştah düzenlemesinde önemli payını gösterir (Trier vd. 2020; Vehapoğlu vd. 2016).

Sadece hiperfaji ya da kilo alımı değil, bozulmuş metabolik faaliyetler, hiperleptinemi, hiperinsülinemi, doğrusal büyümede artış, hipofiz fonksiyonunda bozukluk, glikoz homeostazında dengesizlik, artan yağ kütlesi, azalmış yağsız 
kütle ve azalmış kemik yoğunluğuna sahip canlılar ortaya çıkmaktadır (Anderson vd. 2016; Demidowich vd. 2017). POMC geninin aşırı merkezi ekspresyonu ise farelerde vücut kütlesini uzun süreli olarak azalttığına dair rapor edilmiş çalışma mevcuttur (Côté vd. 2017).

MC4 reseptöründeki mutasyon gen taşıyıcı obez çocuklarda, taşıyıcı olmayan obez çocuklara göre bazı bulgular daha farklıdır. Mutasyon taşıyıcı çocuklarda, davranışsal diyet tedavisinin ve egzersiz müdahalesinin beden kitle indeksi ve kan parametreleri üzerinde daha az olumlu etkisi gözükmektedir. $\mathrm{Bu}$ bulguya göre genetik mutasyonlarda obezite tedavisi için daha farklı müdahaleler gerekebilir (Trier vd. 2020).

Asyada yapılan bir çalışmada MC3R'deki varyantlar sonucu 24 aylık bebeklerde yağlanma artışı olduğu gözlenmiştir. Erken çocukluk çağı yağlanmasıyla ilişkili olması, ileriki yaşlarda obezite gelişimi içinde bir rolü olduğu düşünülmektedir (Aris vd. 2015).

Obez ergenlerin kilo kaybının büyüklügü ile iştah düzenleyici hormonların arasındaki ilişkiyi araştırmak isteyen bir çalışmada, vücut ağırlığının \%10 'undan azını kaybeden ergenlerde, anoreksijenik alfa melanosit uyarıcı hormonda (aMSH) azalma gözlenirken oroksijenik etkili AgRP seviyelerinde artış gözlenmiştir. Yüksek kilo kaybı grubunda ise tam tersi olarak iştah arttırıcı olan nöropeptid Y (NPY) ve agouti ilişkili peptid (AgRP) azalırken, alfa melanosit uyarıcı hormon (a-MSH) artı̧̧ göstermiştir (Kravchychyn vd. 2021).

\section{2. Ödül Merkezi}

Beyinde mezokortikolimbik dopamin sistemi denilen bir ödül merkezi bulunmaktadır. $\mathrm{Bu}$ sistemde gıda ödülünü, motive edilmiş yeme davranışını ve vücut ağırlığını düzenleyen birincil sinirsel devreler bulunur. Dopamin sistemi, başta ventral tegmental alan (VTA)' daki dopamin nöronları olmak üzere birçok kümülatif nöronlardan oluşur. Vücutta dopamin eksikliği veya bloke edilmesi sonucu afajik yeme davranışı gösterildiği çalışmalar mevcuttur. Melanokortin sisteminden a-MSH salınımının MC3R reseptörü aracılığıyla VTA'daki ödül merkezinindeki hücreleri harekete geçirdiği gözlenmiştir. Bu mekanizma yoluyla a MSH gıda alımını ve vücut ağırlığını düzenlemektedir. Melanokortin reseptör agonistilerinin beynin dopamin bölgesine enjeksiyonuyla anlamlı derecede gıda alımını azalttığı da bildirilmiştir (West vd. 2019; Pandit vd. 2016).

\subsection{Stres}

Melanokortin sisteminin araştırmalarda gösterilen bir diğer etkisi de MC4R'ın hipotalamusdaki adrenal aksın aktivasyonu arttırarak; anksiyete ve stres benzeri davranışsal tepkiler oluşturmasıdır. Bu durum yüksek POMC ekspresi yapan insanlarda anoreksik durumun oluşması, gıda alımını azaltıcı ve anoreksiya nevroza gibi yeme bozukluğu olan hastalarda istenmeyen yeme davranışlarıyla da ilişkili olabileceğini düşündürmektedir (Yıldırım, 2020).

\subsection{Beslenme}

Melanokortin sistemi genetik faktörler dışında, sağlıksız ve dengesiz beslenme davranışı ile de sonradan bozulabilir. Primatlar üzerinde yapılan bir çalışmada uzun bir dönem yüksek yağlı diyetle beslenen gebelerin fetüslerinde, proinflamatuar belirteçler hipotalamusta yükselmiştir. Sağlıklı bir diyetle beslenmeye geçen primat annelerde ise melanokortin seviyeleri normal izlenmiştir. $\mathrm{Bu}$ bağlamda, yağdan zengin bir diyetin aşırı tüketiminin, metabolik endokrin sinyallere (leptin ve insülin sinyali gibi) geri bildirimde ve hipotalamik inflamatuar yanıtlarda değişikliklere yol açması dikkat çekici bir durumdur. Mevcut bulgular, gebelik dönemindeki yanlış beslenme sonucu, doğacak bebeğin başta çocukluk çağı obezitesi olmak üzere, tüm hayatını etkileyecek hastalıklara yatkınlığına zemin oluşturmaktadır. Melanokortin sisteminin zarar görmesi ile yaşamlarının ilerleyen dönemlerinde; lipotoksisite, inflamasyon, karaciğer hastalı̆̆ 1 , diyabet gibi metabolik sorunlar görülebilmektedir (Hammad vd. 2020; Sullivan vd. 2017).

Hipotalamik inflamasyon belirteçleri, yüksek yağlı ve şekerli, aşırı beslenme tarzıyla önemli ölçüde artmaktadır. Bunun sonucunda reaktif gliozis ve hipotalamik astrositler gelişir. $\mathrm{Bu}$ da nöronal hasar, insülin ve leptin direnci, vücut ağırlığında artışı ortaya çıkarır (Baldini ve Phelan, 2019; Jais ve Brüning, 2017).

Batı diyeti beslenme tarzıyla yapılmış çalışmalarda, batı diyetinin POMC yolağını bozarak, hiperfajiye ve enerji dengesizliğine neden olduğu bildirilmiştir. Bu beslenme türü, kan-beyin bariyeri geçirgenliğinde nitrik oksit sentaz (iNOS) bağımlı değişikliklerin yanı sıra değişen glikoz metabolizmasıyla hipotalamik makrofajların aktivasyonuna neden olmaktadır. Bunun aksine, sağlıklı ve dengeli beslenmeyle yapılan çalışmalarda özellikle doymamış yağ asitlerinden omega-3'ün beyne enjeksiyonuyla bu enflamatuar etkilerinin azalarak leptin ve insülin duyarlılığını arttırdığına dair kanıtlar sunulmaktadır. Bu durum doğru ve kontrollü beslenmenin obeziteden korunmada ve nöral sağlı̆̆ korumadaki önemli rolünü göstermektedir (Gavini vd. 2020; Bonaventura vd. 2020; Jais ve Brüning, 2017).

\subsection{AMPK}

İskelet kasındaki leptin kaynaklı AMPK aktivasyonunun bir kısmının, merkezi melanokortin sistemi aracılığıyla gerçekleştirildiği çalışmalarla gösterilmiştir. İskelet kası AMP ile aktive olan protein kinaz (AMPK), leptin tarafından aktive olur ve vücutta yağ asidi beta oksidasyonunun ana işlevcisi olarak görev alır. Sentetik melanokortin agonisti AMPK aktivasyonunu arttırarak enerji harcamasını desteklemektedir. $\mathrm{Bu}$ işlev yüksek yağlı ve sağlıksız diyet altında bile enerji dengesini korumaktadır. Ayrıca, leptin direnci olan canlılarda bile melanokortin agonistinin AMPK'yı etkinleştirebileceği bildirilmektedir (Chai vd. 2010). Ayrica leptin hormonunun, MC4R ile aktivasyonu sayesinde kalp yetmezliğine karşı koruyucu özellik gösterdiği çalışmalarda belirtilmiştir (Gava vd. 2021)

\subsection{Egzersiz}

Son çalışmalar, egzersizin ARC POMC nöronlarını aktive ederken aynı zamanda NPY / AgRP nöronlarını inhibe ettiğini, özellikle, egzersiz yapan farelerin POMC nöronlarında egzersizden sonra artan bir uyarıcı sinaptik ton artış1 olduğunu göstermektedir. Egzersiz sırasında ise tam tersi bir duruma rastlanmaktadır (Lieu vd. 2020). Egzersizin 
melanokortin sistemi üzerinde etkisi olduğu gibi melanokortin sistemindeki işlevsel bozukluk egzersiz performansını olumsuz etkilemektedir (Lieu vd. 2020).

\section{7. İmmünoglobulinler}

Vücudumuzda birçok yerde bulunan immünoglobulinler, $\alpha$ MSH ile bağlanarak iştah üzerinde normal ve patolojik şartlarda bazı sonuçlar meydana getirebilir. $\alpha$-MSH-reaktif IgG'nin MC4R ile yetersiz aktive edilmesi obeziteye katkıda bulunabilir. Tam tersi olarak anoreksiya nevrosa ve bulimia gibi yeme bozuklukları olan hastalarda artmış $\alpha$-MSH-reaktif IgG plazma seviyeleri, anoreksik durumu daha da arttırabileceği düşünülmektedir (Lucas vd. 2019).

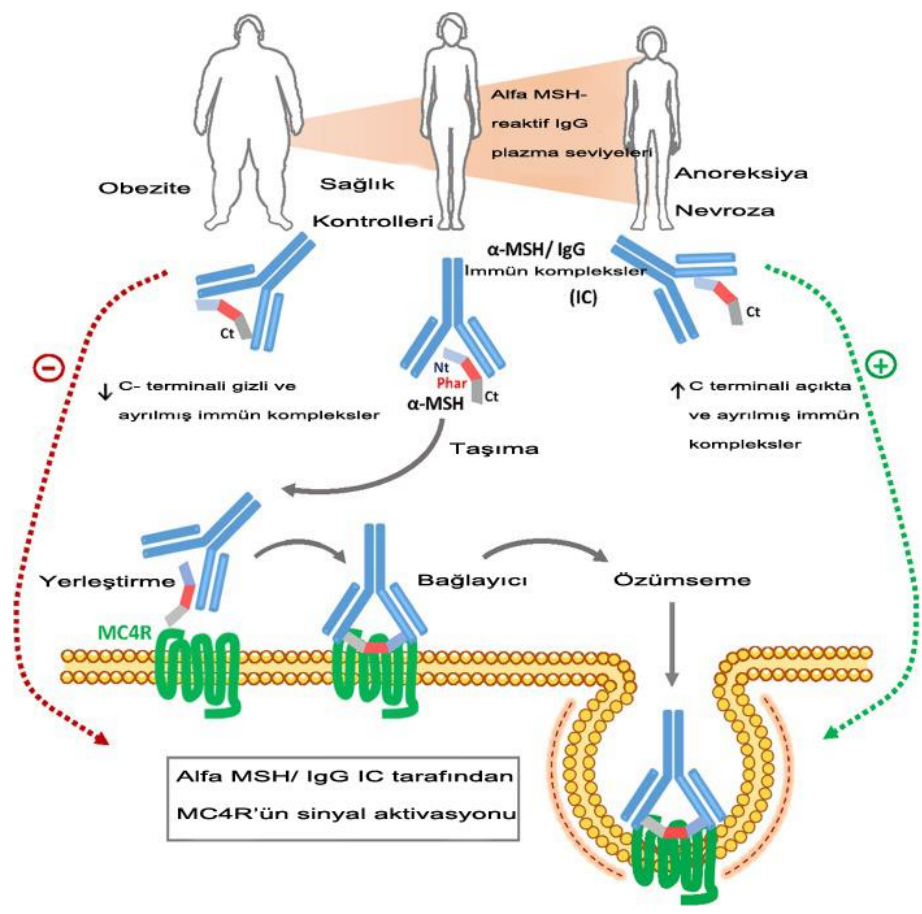

Şekil 3. Sağlıklı, obez ve anoreksiya nevroza hastalarında $\alpha$ melanosit uyarıc1 hormon (a-MSH) / IgG immün kompleksinin (IC) aktivasyon modeli (Lucas vd. 2019)

\subsection{Lipokalin-2}

Lipokalin2' (Lcn2) osteoblast tarafindan besine duyarlı şekilde üretilen bir hormondur. Ve vücutta birçok işlevi bulunmaktadır. Lipokalinler, beyaz yağ hücrelerinde bulunsa da son çalışmalara göre yüksek miktarda osteoblastlarda eksprese edilmektedir (Holland vd. 2019; Palmiter, 2017). Lip-2, aynı zamanda nötrofiller, karaciğer, böbrek ve makrofajların da dâhil olduğu birçok kaynakta bulunmaktadır. Lipokalin-2 glikoz metabolizmasını iyileştirirken iştahı bastırır ve yağ kütlesini azaltmaktadır. Glikozun osteoblastlara taşınmasını sağlayan GLUT1'nin ekspresyonunu sağlayarak kemik bütünlüğünü de korumaktadır (Greenhill, 2017; Capulli vd. 2018).

Lipokalin2 gen dizisinin yokluğu glikoz intolerans1, insülin direnci, azalmış kemik yoğunluğu, hiperfaji ve obezite görülmesine neden olmaktadır (Liang vd. 2021). Lipokalin diyabete karşı koruyucu bir mekanizma sergiler. Lipokalin 2 yemekten sonra beslenme sinyallerine duyarlı olarak kemiklerden kan dolaşımına geçerek vücutta dolaşır ve beynin hipotalamus bölgesinin reseptörlerin olduğu paraventriküler çekirdek kısmına geçer. Buradaki melanokortin 4 reseptörüne (MC4R) bağlanarak anoreksijenik yolu aktive eder. Lipokalin 2'nin bu yolla hücre içi sinyal molekülü olan siklik AMP'nin üretimini uyardığı da bilinmektedir ( Petropoulou vd. 2020). $\mathrm{Bu}$ yolla yă̆ asitleri oksidasyonunu teşvik ettiği düşünülmektedir (Mousialou vd. 2017). Lipokalin 2 hormonu obez kişilerde sağlıklı bireylere göre daha az salgılanmaktadır. Mevcut bir çalışmada ağır bir ögünden sonra normal veya aşırı kilolu kişilerde serum LCN2 düzeyleri arttığ1 ancak obezitesi olan kişilerde artmadığı gösterilmiştir. Bu da leptin direnci gibi LCN2 içinde obez bireylerde bir direnç oluşabileceği düşüncesini ortaya çıkarmaktadır (Palmiter vd. 2017). Bu hormon geninde meydana gelen varyantlar ise abdominal çocukluk obezitesi ve iskelet kası rejenerasyonu bozukluğu ile ilişkilendirilmiştir (Morell-Azanza vd. 2019, Liang vd. 2021, Rebalka vd. 2018).

\section{Sonuç}

Melanokortin sistemi vücudun enerji dengesinin korunmasında oldukça önemli bir sistemdir. Bu sistemdeki gen ifadelerin yokluğu veya yüksek yağlı ve şekerli besinlerin bu yolağı inhibe etmesi obezite başta olmak üzere birçok metabolik hastalığa sebep olmaktadır. Diyete bağlı ya da gen ifadesine bağlı gelişen obezitelerde, diyet tedavisinin iyileştirebilir gücü birçok çalışmada vurgulanmaktadır. Yeme bozuklukları, besin alımı, kombine diyetlerin etkisi ve metabolik hastalıklara etkisinin daha iyi anlaşılabilmesi için bu sistemle ilgili daha fazla çalışmaya ihtiyaç vardır.

\section{Kaynaklar}

Anderson, E. J. P., Çakir, I., Carrington, S. J., Cone, R. D., Ghamari-Langroudi, M., Gillyard, T., Litt, M. J. (2016). 60 YEARS OF POMC: Regulation of feeding and energy homeostasis by $\alpha-\mathrm{MSH}$. Journal of Molecular Endocrinology, 56(4), T157-T174. https://doi.org/10.1530/jme-16-0014

Aris, I. M., Tint, M. T., Teh, A. L., Holbrook, J. D., Quah, P. L., Chong, M. F., . . Lee, Y. S. (2015a). MC3R gene polymorphisms are associated with early childhood adiposity gain and infant appetite in an Asian population. Pediatric Obesity, 11(6), 450-458. https://doi.org/10.1111/ijpo.12086

Baldini, G., \& Phelan, K. D. (2019). The melanocortin pathway and control of appetite-progress and therapeutic implications. Journal of Endocrinology, 241(1), R1-R33. https://doi.org/10.1530/joe-18-0596

Butler, A. A., Girardet, C., Mavrikaki, M., Trevaskis, J. L., Macarthur, H., Marks, D. L., \& Farr, S. A. (2017). A Life without Hunger: The Ups (and Downs) to Modulating Melanocortin-3 Receptor Signaling. Frontiers in Neuroscience, 11. Published. https://doi.org/10.3389/fnins.2017.00128

Capulli, M., Ponzetti, M., Maurizi, A., Gemini-Piperni, S., Berger, T., Mak, T. W., . . . Rucci, N. (2018). A Complex Role for Lipocalin 2 in Bone Metabolism: Global Ablation in Mice Induces Osteopenia Caused by an Altered Energy Metabolism. Journal of Bone and Mineral Research, 33(6), 1141-1153. 
https://doi.org/10.1002/jbmr.3406

Chai, B., Li, J. Y., Zhang, W., Wu, X., Zhang, C., \& Mulholland, M. W. (2010). Melanocortin-4 receptor activation promotes insulin-stimulated mTOR signaling. Peptides, 31(10), 1888-1893. https://doi.org/10.1016/j.peptides.2010.06.028

Côté, I., Sakarya, Y., Kirichenko, N., Morgan, D., Carter, C., Tümer, N., \& Scarpace, P. (2017). Activation of the central melanocortin system chronically reduces body mass without the necessity of long-term caloric restriction. Canadian Journal of Physiology and Pharmacology, 95(2), 206-214. https://doi.org/10.1139/cjpp-2016-0290

Demidowich, A. P., Jun, J. Y., \& Yanovski, J. A. (2017). Polymorphisms and mutations in the melanocortin-3 receptor and their relation to human obesity. Biochimica et Biophysica Acta (BBA)- Molecular Basis of Disease, 1863(10), 2468-2476. https://doi.org/10.1016/j.bbadis.2017.03.018

Ericson, M. D., Lensing, C. J., Fleming, K. A., Schlasner, K. N., Doering, S. R., \& Haskell-Luevano, C. (2017). Bench-top to clinical therapies: A review of melanocortin ligands from 1954 to 2016. Biochimica et Biophysica Acta (BBA) - Molecular Basis of Disease, 1863(10), 2414-2435. https://doi.org/10.1016/j.bbadis.2017.03.020

Garfield, A. S., Li, C., Madara, J. C., Shah, B. P., Webber, E., Steger, J. S., . . Lowell, B. B. (2015). A neural basis for melanocortin-4 receptor-regulated appetite. Nature Neuroscience, 18(6), 863-871. https://doi.org/10.1038/nn.4011

Gava, F. N., da Silva, A. A., Dai, X., Harmancey, R., Ashraf, S., Omoto, A. C., . . . do Carmo, J. M. (2021b). Restoration of Cardiac Function After Myocardial Infarction by Long-Term Activation of the CNS Leptin-Melanocortin System. JACC: Basic to Translational Science, 6(1), 55-70. https://doi.org/10.1016/j.jacbts.2020.11.007

Gavini, C. K., Cook, T. M., Rademacher, D. J., \& MansuyAubert, V. (2020). Hypothalamic C2-domain protein involved in MC4R trafficking and control of energy balance. Metabolism, 102, 153990. https://doi.org/10.1016/j.metabol.2019.153990

Glas, E., Mückter, H., Gudermann, T., \& Breit, A. (2016). Exchange factors directly activated by cAMP mediate melanocortin 4 receptor-induced gene expression. $\begin{array}{llll}\text { Scientific } & \text { Reports, } & 6(1), & 1 .\end{array}$ https://doi.org/10.1038/srep32776

Greenhill, C. (2017). Osteoblast-derived lipocalin 2 suppresses appetite. Nature Reviews Endocrinology, 13(5), 250. https://doi.org/10.1038/nrendo.2017.30

Hammad, M. M., Abu-Farha, M., Hebbar, P., Cherian, P., al Khairi, I., Melhem, M., . . Abubaker, J. (2020). MC4R Variant rs 17782313 Associates With Increased Levels of DNAJC27, Ghrelin, and Visfatin and Correlates With Obesity and Hypertension in a Kuwaiti Cohort. Frontiers in Endocrinology, 11. Published. https://doi.org/10.3389/fendo.2020.00437

Haws, R., Brady, S., Davis, E., Fletty, K., Yuan, G., Gordon, G., . . Y Yanovski, J. (2020). Effect of setmelanotide, a melanocortin-4 receptor agonist, on obesity in BardetBiedl syndrome. Diabetes, Obesity and Metabolism, 22(11),

2133-2140. https://doi.org/10.1111/dom.14133

Holland, J., Sorrell, J., Yates, E., Smith, K., Arbabi, S., Arnold, M., . . . Perez-Tilve, D. (2019). A BrainMelanocortin-Vagus Axis Mediates Adipose Tissue Expansion Independently of Energy Intake. Cell Reports, 27(8), 2399-2410.e6. https://doi.org/10.1016/j.celrep.2019.04.089

Huang, T., Zheng, Y., Hruby, A., Williamson, D. A., Bray, G. A., Shen, Y., . . . Qi, L. (2017). Dietary Protein Modifies the Effect of the MC4R Genotype on 2-Year Changes in Appetite and Food Craving: The POUNDS Lost Trial. The Journal of Nutrition, jn242958. https://doi.org/10.3945/jn.116.242958

Jais, A., \& Brüning, J. C. (2017). Hypothalamic inflammation in obesity and metabolic disease. Journal of Clinical Investigation, $\quad 127(1), \quad 24-32$. https://doi.org/10.1172/jci88878

Khodarahmi, M., Kahroba, H., Jafarabadi, M. A., MesgariAbbasi, M., \& Farhangi, M. A. (2020). Dietary quality indices modifies the effects of melanocortin-4 receptor (MC4R) rs17782313 polymorphism on cardiometabolic risk factors and hypothalamic hormones in obese adults. BMC Cardiovascular Disorders, 20(1). https://doi.org/10.1186/s12872-020-01366-8

Kim, J. D., Leyva, S., \& Diano, S. (2014). Hormonal regulation of the hypothalamic melanocortin system. Frontiers in Physiology, 5. Published. https://doi.org/10.3389/fphys.2014.00480

Kravchychyn, A. C. P., Campos, R. M. D. S., Oliveira E Silva, L., Ferreira, Y. A. M., Corgosinho, F. C., Masquio, D. C. L., . . Dâmaso, A. R. (2021c). Adipocytokine and appetite-regulating hormone response to weight loss in adolescents with obesity: Impact of weight loss magnitude. Nutrition, 87-88, 111188. https://doi.org/10.1016/j.nut.2021.111188

Li, L., Liang, J., Zhang, C., Liu, T., \& Zhang, C. (2021). Peripheral actions and direct central-local communications of melanocortin 4 receptor signaling. Journal of Sport and Health Science. Published. https://doi.org/10.1016/j.jshs.2021.02.001

Lieu, L., Chau, D., Afrin, S., Dong, Y., Alhadeff, A. L., Betley, J. N., \& Williams, K. W. (2020). Effects of metabolic state on the regulation of melanocortin circuits. Physiology \& Behavior, 224, 113039. https://doi.org/10.1016/j.physbeh.2020.113039

López, M. (2018). Central leptin and autonomic regulation: A melanocortin business. Molecular Metabolism, 8, 211213. https://doi.org/10.1016/j.molmet.2018.01.001

Lucas, N., Legrand, R., Bôle-Feysot, C., Breton, J., Coëffier, M., Akkermann, K., . . . Fetissov, S. O. (2019). 
Immunoglobulin $\mathrm{G}$ modulation of the melanocortin 4 receptor signaling in obesity and eating disorders. Translational Psychiatry, $9(1)$. https://doi.org/10.1038/s41398-019-0422-9

Micioni Di Bonaventura, E., Botticelli, L., Tomassoni, D., Tayebati, S. K., Micioni Di Bonaventura, M. V., \& Cifani, C. (2020b). The Melanocortin System behind the Dysfunctional Eating Behaviors. Nutrients, 12(11), 3502. https://doi.org/10.3390/nu12113502

Morell-Azanza, Ojeda-Rodríguez, Giuranna, AzconaSanJulián, Hebebrand, Marti, \& Hinney. (2019). Melanocortin-4 Receptor and Lipocalin 2 Gene Variants in Spanish Children with Abdominal Obesity: Effects on BMI-SDS After a Lifestyle Intervention. Nutrients, 11(5), 960. https://doi.org/10.3390/nu11050960

Mosialou, I., Shikhel, S., Liu, J. M., Maurizi, A., Luo, N., He, Z., . . Kousteni, S. (2017). Erratum: Corrigendum: MC4R-dependent suppression of appetite by bonederived lipocalin 2. Nature, 546(7658), 440. https://doi.org/10.1038/nature22808

Mountjoy, K. G. (2015). Pro-Opiomelanocortin (POMC) Neurones, POMC-Derived Peptides, Melanocortin Receptors and Obesity: How Understanding of this System has Changed Over the Last Decade. Journal of Neuroendocrinology, 27(6), 406-418. https://doi.org/10.1111/jne.12285

Palmiter, R. D. (2017). Bone-derived hormone suppresses appetite. Nature, 543(7645), 320-321. https://doi.org/10.1038/nature21501

Pandit, R., Omrani, A., Luijendijk, M. C. M., de Vrind, V. A. J., van Rozen, A. J., Ophuis, R. J. A. O., . . Adan, R. A. H. (2016a). Melanocortin 3 Receptor Signaling in Midbrain Dopamine Neurons Increases the Motivation for Food Reward. Neuropsychopharmacology, 41(9), 2241-2251. https://doi.org/10.1038/npp.2016.19

Petropoulou, P. I., Mosialou, I., Shikhel, S., Hao, L., Panitsas, K., Bisikirska, B., . . Kim, J. (2021). Lipocalin-2 is an anorexigenic signal in primates. Yearbook of Paediatric Endocrinology. Published. https://doi.org/10.1530/ey.18.14.2

Rebalka, I. A., Monaco, C. M. F., Varah, N. E., Berger, T., D'souza, D. M., Zhou, S., . . Hawke, T. J. (2018). Loss of the adipokine lipocalin-2 impairs satellite cell activation and skeletal muscle regeneration. American Journal of Physiology-Cell Physiology, 315(5), C714C721. https://doi.org/10.1152/ajpcell.00195.2017

Rinne, P., Rami, M., Nuutinen, S., Santovito, D., van der Vorst, E. P., Guillamat-Prats, R., . . . Steffens, S. (2017b). Melanocortin 1 Receptor Signaling Regulates Cholesterol Transport in Macrophages. Circulation, 136(1), 83-97. https://doi.org/10.1161/circulationaha.116.025889

Sullivan, E. L., Rivera, H. M., True, C. A., Franco, J. G., Baquero, K., Dean, T. A., . . Kievit, P. (2017b). Maternal and postnatal high-fat diet consumption programs energy balance and hypothalamic melanocortin signaling in nonhuman primate offspring. American Journal of PhysiologyRegulatory, Integrative and Comparative Physiology, 313(2),

R169-R179.

https://doi.org/10.1152/ajpregu.00309.2016

Suyama, S., Ralevski, A., Liu, Z., Dietrich, M. O., Yada, T., Simonds, S. E., . . Horvath, T. L. (2017, August 1). Plasticity of calcium-permeable AMPA glutamate receptors in Pro-opiomelanocortin neurons. Retrieved from https://elifesciences.org/articles/25755

Toda, C., Santoro, A., Kim, J. D., \& Diano, S. (2017). POMC Neurons: From Birth to Death. Annual Review of Physiology, 79(1), 209-236. https://doi.org/10.1146/annurev-physiol-022516034110

Trier, C., Hollensted, M., Schnurr, T. M., Lund, M. A. V., Nielsen, T. R. H., Rui, G., Andersson, E. A., Svendstrup, M., Bille, D. S., Gjesing, A. P., Fonvig, C. E., Frithioff-Bøjsøe, C., Balslev-Harder, M., Quan, S., Gamborg, M., Pedersen, O., Ängquist, L., Holm, J.-C., \& Hansen, T. (2020). Obesity treatment effect in Danish children and adolescents carrying Melanocortin-4 Receptor mutations. International Journal of Obesity, 45(1), 66-76. Published. https://doi.org/10.1530/ey.18.11.5

van der Klaauw, A. A., Keogh, J. M., Henning, E., Stephenson, C., Kelway, S., Trowse, V. M., . . . Farooqi, I. S. (2016). Divergent effects of central melanocortin signalling on fat and sucrose preference in humans. Nature Communications, 7(1). https://doi.org/10.1038/ncomms13055

Vehapoğlu, A., Türkmen, S., \& Terzioğlu, U. (2016). AlphaMelanocyte-Stimulating Hormone and Agouti-Related Protein: Do They Play a Role in Appetite Regulation in Childhood Obesity? Journal of Clinical Research in Pediatric Endocrinology, 8(1), 40-47. https://doi.org/10.4274/jcrpe.2136

West, K. S., Lu, C., Olson, D. P., \& Roseberry, A. G. (2019). Alpha-melanocyte stimulating hormone increases the activity of melanocortin-3 receptor-expressing neurons in the ventral tegmental area. The Journal of Physiology, 597(12), 3217-3232. https://doi.org/10.1113/jp277193

Xu, Y., Elmquist, J. K., \& Fukuda, M. (2011). Central nervous control of energy and glucose balance: focus on the central melanocortin system. Annals of the New York Academy of Sciences, 1243(1), 1-14. https://doi.org/10.1111/j.1749-6632.2011.06248.x

Yeo, G. S., Chao, D. H. M., Siegert, A. M., Koerperich, Z. M., Ericson, M. D., Simonds, S. E., ... Adan, R. A. (2021). The melanocortin pathway and energy homeostasis: From discovery to obesity therapy. Molecular Metabolism, 48, 101206. https://doi.org/10.1016/j.molmet.2021.101206

Y1ldırım, A. (2020, February 8). Batı-tipi diyetin davranışsal etkileri üzerine melanokortin 4 reseptör agonisti rm493'ün etkileri. Marmara University. 
Yu, J., Gimenez, L. E., Hernandez, C. C., Wu, Y., Wein, A.

H., Han, G. W., . . . Stevens, R. C. (2020).

Determination of the melanocortin-4 receptor structure

identifies $\mathrm{Ca} 2+$ as a cofactor for ligand binding.

Science, 368(6489), 428-433.

https://doi.org/10.1126/science.aaz8995 